\title{
The Impact Of Oil Prices On Sectorial Employment In South Africa
}

Sibanda Kin, University of Fort Hare, South Africa

Mishi Syden, University of Fort Hare, South Africa

Tsegaye Asrat, University of Fort Hare, South Africa

\begin{abstract}
Failure to create more jobs is a problem faced by many African countries, and South Africa is not spared. Evidence concerning the effect of oil prices on employment is lacking. The paper examines the impact of factor prices (oil prices) on sectorial employment in South Africa over the period 1994 to 2012 using quarterly data.

The study employs panel data analysis techniques to split the sectorial effects. The use of panel data econometric techniques to control for unobserved heterogeneity is essential to uncover the result, which is completely hidden in OLS estimates. By adding a dummy of each sector, pure effect of oil prices are estimated through controlling for unobserved heterogeneity. The effect of oil prices is felt most in the finance sector, followed by construction, then trade - all significant at 1\%. Since oil price is positively related to employment in these sectors, it implies that the monetary policy in South Africa is accommodative as given a wage rate, increase in the price of oil leads to increase in price level and thus decrease in real wage.
\end{abstract}

Keywords: Oil Prices; Sectorial Employment; Panel Regression; South Africa

\section{INTRODUCTION AND BACKGROUND}

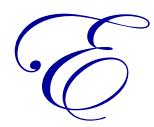

mployment is regarded as a critical economic performance indicator of any country. It fulfills key economic developmental roles, such as poverty alleviation and reduction in income inequality, and helps address rural underdevelopment and, as such, is considered as a measure of economic success and a macroeconomic objective of most nations (Bletcher, Thomas, Muradzikwa, Smith and De Villiers, 2009). In an attempt to fulfill and achieve employment as a macroeconomic objective, South Africa has implemented several growth support programs aimed at stimulating job creating economic growth since 1994 (Knight, 2001). These growth support programs ranged from the reconstruction and development program (RDP) of 1994 and the Growth, Employment and Redistribution (GEAR) program of 1996, the Accelerated and Shared Growth Initiative of South Africa (ASGISA) program of 2006, and the New Growth Path (NGP) program of 2010. Despite the implementation of all these growth support programs, which managed to make a substantial improvement in employment creation, in 2010 South Africa was still ranked amongst the ten countries with the lowest levels of employment worldwide (NGP, 2010). Thus, since 1994, the South African economy has not managed to create sufficient employment opportunities, as evidenced by a relatively high average unemployment rate of 25.49 percent for the period 2000 2012. The South African unemployment rate reached a record all time high of 31.20 percent in March 2003 and a record low of 21.90 percent in December 2008 (Trading Economics, 2012). Given such alarming rates, it becomes imperative to investigate the possible causes of unemployment to help understand the possible drivers in South Africa. Previous scholars, such as Dogrul and Soytas (2010) and Ahmad (2013), have considered oil prices as the main cause of unemployment.

The importance of oil as a factor of production has augmented worldwide since 2001, where it accounted for 37 percent of the world's primary energy supply (Wakeford, 2006). As an essential component of transportation liquid fuel in a country where there are limited oil reserves, oil accounts for 6 percent of South Africa's total imports (EIA, 2013). Given the significance of oil to the South African economy, the movement of oil prices should be 
regarded as a matter of primary concern as it influences macroeconomic policy formulation. Oil prices have been revealed to predict employment and cause unemployment, which is a macroeconomic and political problem for most governments, especially in South Africa (Ahmed, 2013; Dogrul and Soytas, 2010).

Previous studies (Ahmad, 2013; Herrera and Karaki, 2012; Keane and Prasad, 1996) have used various transmission channels to explain the employment impact of oil prices. For instance, Ahmad (2013) suggested that from a supply side, oil prices have a positive effect on unemployment in the long run. Specifically, a rise in oil prices leads to a fall in output levels, which results from higher production costs and ultimately causes an increase in unemployment. In addition, Ahmad (2013) suggested that from the demand perspective, oil prices have a negative effect on consumption and investment and, ultimately, employment. For example, an increase in oil prices leads to higher interest rates, reduces both investment and consumption, and eventually causes a fall in employment and a rise in unemployment. From the sector adjustment side, oil prices were considered to have a positive effect on interest and/or unemployment rates (Ahmad, 2013). In other words, an increase in oil prices leads to higher interest rates and higher unemployment rates, which means lower levels of employment. On the contrary, Keane and Prasad (1996) suggested that an increase in oil prices has a negative impact on aggregate employment in the short run and a positive impact in the long run.

In light of the above, there seems to be a lack of consensus from previous studies regarding the employment effect of oil prices, Empirical evidence in developed nations confirms a positive effect of oil prices in the long run (Keane and Prasad, 1996) while in developing nations, the evidence suggests a negative effect of oil prices in the long run (Ahmed, 2013). Previous studies on the subject matter have examined the relationship between oil prices and employment in the developed nations, such as America (Herrera and Karaki, 2012; Keane and Prasad, 1996) and Turkey (Dogrul and Soytas, 2010), and rarely can one find such studies in the developing nations' context. The notable exception is Ahmad (2013)'s study which focused on Pakistan. In the South African context, previous studies have investigated the impact of oil price shocks or oil price movements on the macro economy (Nkomo, 2006) and on the South African economy as a whole (Chisadza, Dlamini, Gupta and Modise, 2013; Wakeford, 2006).

In addition, in the South African context, those that studied employment investigated the impact of other factors such as exchange rates (Ngandu, 2009) and economic growth (Leibbrandt, Woolard, McEwen and Koep, 2010). More so, for those studies that have examined the impact of oil prices in the developed nations, a majority of them focused on economic growth and aggregate employment (Dogrul and Soytas, 2010; Keane and Prasad, 1996). Thus, not much has been done in examining how oil prices affect employment in different sectors of the economies (notable exceptions are Ahmad, 2013; Herrera and Karaki, 2012). As such, the employment impact on oil prices in different sectors of the African economy, particularly South Africa, appears to be a neglected area of study despite the macroeconomic policy implications of such a study of the countries. Therefore, this study seeks to explore the impact of oil prices on sectorial employment in the South African context.

\section{THEORETICAL LITERATURE}

The study employs three transmission channels to explain the impact of oil prices on employment in South Africa. The transmission channels include the supply side effect, demand side effect, and the sector adjustment effect.

\section{The Supply Side Effect Channel}

The supply side effect channel explains the impact of oil prices on employment through output levels and costs (Beaudreau, 2005). This channel postulates that, on one hand, an increase in the prices of oil, which is considered as a basic production input, leads to increased production costs which in turn results in a decrease in output levels, a fall in employment and ultimately an increase in the unemployment rate (Ahmad, 2013). On the other hand, a decrease in oil prices leads to lower production costs, which encourages higher production and results in higher levels of output and employment while reducing the unemployment rate. Given that South Africa is a country that highly imports oil as a factor of production, this paper postulates a negative relationship between oil prices and employment. Thus, an increase in oil prices is expected to reduce employment through increased 
production costs that will reduce the output levels in South Africa, thereby increasing sectorial unemployment. A decrease in oil prices is expected to increase employment in South Africa through a decrease in production costs which will stimulate production and output levels while reducing unemployment.

\section{The Demand Side Effect Channel}

The demand side effect channel explains the impact of oil prices on employment through consumption and investment. The channel posits that oil prices have a negative effect on consumption and investment (Ahmad, 2013). According to this channel, an increase in oil prices results in an increase in interest rate - the cost of borrowing. As suggested by Ahmad (2013), capital is a primary input for industries that come from both local and foreign investments and normally comes from borrowing. Thus, a higher interest rate implies a higher cost of borrowing for investors, which will lead to a decline in investment and ultimately employment. To the households, a higher interest rate implies a higher cost of money for consumption, thus the higher interest rates lead to a fall in consumption and eventually a decrease in employment. On the other hand, a fall in oil prices leads to lower interest rates, lower cost of borrowing for both consumption and investment, which, in turn, increases consumption and investment and, ultimately, employment (Brown and Yucel, 2002). In the South African context, from a demand side, this study therefore posits a negative effect of oil prices on employment through the rising oil prices' adverse effects on consumption and investment.

\section{The Sector Adjustment Effect Channel}

The sector adjustment effect channel was postulated by Beaudreau (2005) and explains the effect of oil prices on unemployment through the relative production costs of some industrial sectors. This channel argues that long-term oil price shocks have major implications on the production costs and ultimately on the unemployment rate (Beaudreau, 2005). Thus, an increase in oil prices leads to higher production costs, which results in a change in the production setup, leading to different labour skills requirements than before for industry sectors that primarily use oil as an energy source (Ahmad, 2013). Ultimately, unemployment will result as skills cannot be developed in days and new job searches are time-consuming (Ahmad, 2013). Therefore, an increase in oil prices to highly oildependent industry sectors will result in high unemployment (Ahmad, 2013), mainly because each individual employee has some industry-specific skills which cannot be absorbed in other industry sectors, making the unemployed workers unemployable in other industry sectors (Beaudreau, 2005)). Subsequently, an oil price rise in a labour intensive industry sector that uses oil as a primary source of energy leads to higher levels of job reallocation and high unemployment rates (Ahmad, 2013).

\section{EMPIRICAL LITERATURE REVIEW} countries.

This section provides empirical evidence from previous studies in both developing and developed

Herrera and Karaki (2012) investigated the impact of oil price innovations on job creation and job destruction in the United States of America's manufacturing sector. The paper also examined whether the size of sectorial job creation and destruction, a year after an oil price shock, was equal for both the positive and negative oil price innovations of a typical and a large magnitude. A structural model comprising the IRFs of Killian and Vigfusson (2011) to estimate the effect of oil price on sectorial job creation and destruction, as well as cumulative net changes in employment, was used together with the Ordinary Least Squares (OLS) to estimate the model. The findings of the paper indicated that oil price innovations lead to an intensive job allocation process. More so, the findings suggested that following an unexpected oil price rise, firms tend to reduce jobs at a faster rate than that at which they create jobs. This in turn results in a decrease in net employment and a rise in labour reallocation and the labour reallocation process was reported to be statistically significant for several sectors that intensively used energy in production.

Dogrul and Soytas (2010) examined the relationship between oil prices, interest rates and unemployment in Turkey. The study employed the Toda-Yamamoto procedure and found that the real price of oil and the interest rate improve the forecasts of unemployment. More so, the findings of the study indicated that oil price and interest rate granger caused unemployment and a positive link was reported between oil prices and unemployment. 
A study by Keane and Prasad (1996) examined the effects of oil price changes on employment and real wages at aggregate and industry levels in the United States of America. Using micro panel data econometric techniques, the findings of the study indicated that oil price increases have a negative effect on aggregate employment in the short run and a positive effect on aggregate employment in the long run. More so, the findings revealed that oil price induces reallocation of labour across industries.

Ahmad (2013) investigated the relationship between oil prices and unemployment in Pakistan. The study employed monthly data for the period 1991-2000 and made 238 observations for each variable. Using a vector auto regression (VAR) model and the Toda-Yamamoto causality test, the findings of the study revealed that real oil prices have a significant effect on unemployment. Furthermore, the findings of the study showed that oil price granger caused unemployment in the long run.

Ngandu (2009) examined the impact of a rand appreciation on employment in South Africa. The study employed the computable general equilibrium model. The results showed that a rand appreciation improves employment in the nontraded sectors, while in the traded sectors a negative effect of the rand appreciation on employment was reported.

Chisadza, Dlamini, Gupta and Modise (2013) examined the impact of oil supply and demand shocks on the South African economy. The study employed a sign restriction-based structural Vector Auto-Regressive (VAR) model. The findings of the study indicated that an oil supply shock has a significantly short-lived impact only on the inflation rate, while a statistically insignificant impact on other variables was reported. In addition, a negative effect of oil specific demand shocks on inflation rate and real exchange rate was revealed.

Nkomo (2006) investigated the impact of crude oil on South Africa. The study followed a history and literature analysis method and concluded that South Africa has been shielded from much of the negative impacts of crude oil price increases resulting from its strong US Dollar/Rand exchange rate, although it is still vulnerable to external sources of oil supply and to increases in international oil prices. More so, the study concluded that high crude oil prices have an immediate impact on economic growth and development of the oil-consuming country.

From the reviewed literature, it is clear that oil prices have a significant effect on the macro economy in different countries, including South Africa. The impact of oil prices can be positive or negative and differs across countries and sectors. Since the seminal works of Hamilton (1983) and Burbidge and Harrison (1984), a causal relationship has been identified between oil price changes and variations in macroeconomic indicators, such as GNP and the unemployment rate in the US, with causality running from the former to the latter. However, limited work is available for developing countries like South Africa, let alone sectorial analysis. A significant body of economic literature focused on the impact of oil prices on the economies of the developed world. Also, a number of studies focused on oil-exporting countries, but not much has been done on oil-importing countries like South Africa.

\section{METHODOLOGY}

Various transmission channels exist through which oil prices may have an impact on economic activity. Informed by the work of Blanchard and Gali (2007), this study sought to investigate the impact of oil prices on sectorial employment with a model specified as follows:

$Y_{i t}=\alpha+\beta_{1} X_{t}+\beta_{2} M E_{t}+\varepsilon_{t}$

where $\mathrm{Y}$ stands for employment, $\mathrm{X}$ is oil prices, $\mathrm{i}$ denotes the sector, $\mathrm{t}$ is time, and $\mathrm{ME}$ represents macroeconomic control variables. The sectors include both private (mining, manufacturing, construction, financial institutions and trade) and public (general government and business enterprises)

For empirical estimations, the study first investigated the simple linear regression model above and then considered the natural logarithm of the series (with and without constant) as in equations 2 and 3 . A change in employment was considered as the variables as compared to just level of employment. 
$\operatorname{DLN}\left(Y_{i t}=\alpha+\beta \cdot L N\left(X_{t}\right)+\varepsilon_{t}\right.$

$\operatorname{DLN}\left(Y_{i t}\right)=\beta \cdot \operatorname{LN}\left(X_{t}\right)+\varepsilon_{t}$

Rajhi, Benabdallah and Hmissi (2005) argue that the estrangement in the relationship between oil price and the macroeconomic variables is due to the problem of default specification in the term of oil price, and not the waning effect in the direct relationship. It follows, then, that the oil price in level (LNOILPRICE) does not have a significant effect on the macroeconomy (employment variable in this case); however, the oil price variations (DLNOILPRICE) do. Consequently, researchers have used the oil price variations (DLNOILPRICE) thereafter, instead of the oil price (LNOILPRICE) in level. Therefore, finally, given the above observations from literature, a simple linear regression between $\operatorname{DLN}\left(\mathrm{Y}_{\mathrm{it}}\right)$ and DLN (Xt) was conducted from two following equations:

$\operatorname{DLN}\left(\mathrm{Y}_{\mathrm{it}}\right)=\alpha+\beta \cdot \operatorname{DLN}\left(\mathrm{X}_{\mathrm{t}}\right)+\varepsilon_{\mathrm{t}}$

$\operatorname{DLN}\left(\mathrm{Y}_{\mathrm{it}}\right)=\beta \cdot \operatorname{DLN}\left(\varepsilon_{\mathrm{t}}\right)$

\section{Variables And Data Sources}

Employment is the dependent variable accounting for the number of people providing labour services to the different economic sectors in South Africa. The variable is, in index form, capturing employment in both the public and private sectors. Under the public sector, two sub-sectors - general government and business enterprises - were used. Private sector analysis is divided into five sub-sectors - mining, manufacturing, construction, financial institutions and trade. These seven sub-sectors were chosen mainly due to the availability of data. Oil prices are the main explanatory variable that represents the Brent crude oil price in US Dollars. The data were sourced from the SARB online query and Quantec Easy Data.

\section{Sectorial Analysis- Panel Estimation}

The main focus of this study is to have a sectorial analysis. To this panel analysis, techniques were employed that separate the sectorial effects. There are up to seven sub-sectors - two in the public sector (general government and government enterprises) and five in the private sector (mining, manufacturing, construction, trade and finance). Table 1 presents the checking with sector effects.

Table 1: Checking With Sector Effects

\begin{tabular}{lccc}
\hline \multicolumn{1}{c}{ Variable } & Coefficient & t value & p value \\
\hline Employment & & & 0.000 \\
\hline Oil Prices & 1.62 & 9.15 & 0.295 \\
\hline Government General Government & 22.94 & 1.05 & 0.001 \\
\hline Construction & 72.55 & 3.30 & 0.000 \\
\hline Finance & 412.40 & 18.78 & 0.150 \\
\hline Mining & 31.62 & 1.44 & 0.507 \\
\hline Manufacturing & 14.59 & 0.66 & 0.014 \\
\hline Trade & 54.11 & 2.46 & 0.577 \\
\hline -cons & 9.83 & 0.56 & \\
\hline
\end{tabular}

By adding a dummy of each sector, pure effect of oil prices are estimated through controlling for unobserved heterogeneity. The effect of oil prices is felt most in the finance sector, followed by construction, then trade - all significant at $1 \%$. Surprising the mining and manufacturing sectors, which are assumed to be mainly affected by oil price movements, is not significant. It is imperative to note here that all the sectors experience an increase in employment due to oil price increases. Since oil price is positively related to employment in these sectors, it implies that the monetary policy in South Africa is accommodative as given a wage rate, increase in the price of oil leads to an increase in price level and thus decrease in real wage. A decrease in real wages, in the environment of sticky wages (as the South African Labour market characterised by sticky rigid policies), results in lower real wages being paid, thereby encouraging firms in the private sector (mostly) to increase employment. This 
effect is highly significant - at $1 \%$ - and is also consistent with Keane and Prasad (1996) who argued that oil prices do not have an adverse effect on aggregate employment in the long run, even though they reduce the real wage. Keane and Prasad (1996) further explain that if oil and labour are net - but not gross - substitutes in production, an increase in oil prices may cause labour supply to shift to the right because they cause long-lived wage declines resulting in a positive income effect, hence giving an incentive to producers to hire more workers. For a robustness check, an alternative estimation was done and the results are presented in Table 2, based on areg STATA command which is designed for datasets with many groups, but not a number of groups, that increases with the sample size. McCaffrey, Mihaly, Lockwood, and Sass (2012) demonstrated the applications which can be explained more by way of an example here, considering two different samples from the South African economy. In the first sample, let us assume there are $\mathrm{N}$ products and a study is interested in the inclusion of an indicator for each of the seven groups (sectors in this study), whereas in the second sample, there are - say three - observations on each of $\mathrm{N}$ products and the desire is to have an indicator for each unit. Areg was designed for datasets similar to the first sample where there is a fixed number of groups - seven economic sectors based on this study. The areg output shows a test that all coefficients, excluding the dummies and the constant, are equal to zero.

Table 2: Areg - Quick Glimpse And Summarised Results

\begin{tabular}{lccc}
\hline \multicolumn{1}{c}{ Employment } & Coefficient & t value & p value \\
\hline Oil Prices & 1.62 & 9.15 & 0.000 \\
\hline -cons & 96.43 & 9.47 & 0.000 \\
\hline sek & $\mathrm{F}(6,519)=$ & 87.467 & 0.000 \\
\hline
\end{tabular}

According to Hamilton (2006), although areg output is less informative than the regression one, it has the advantage of speeding up exploratory work, providing quick feedback as to whether or not a dummy variable approach is worthwhile. The test is significant, also indicating the dummy variable is indeed worthwhile.

There are many factors that affect employment that can be controlled for. Table 3 presents results for a model controlling for macroeconomic factors, specifically real effect exchange rate (reer), gross domestic product (gdp), and labour productivity (lp), all logged together with oil prices (oip). The results indicate that all selected macroeconomic variables significantly affect employment, with labour productivity the only variable having a negative effect. This identified negative relationship implies that the more productive the labour force is, the lower employment within the economy will be. Orgnanisations are reluctant to add more labor when the current is productive or, put differently, even though labour can be highly productive, it is not easy to replace capital, thus labour-capital substitution in South Africa is limited.

Under random effects assumption as presented in Table 3, log of gross domestic product, oil prices, labour productivity and real exchange rates are significantly related to employment, with only labour productivity being negative. Labour productivity reduces employment in the sense that if the engaged workforce is highly productive, the output will be optimal to the point that firms may not see a reason to employ more. However, this is contrary to conventional thinking that employment should be high since labour is relatively productive than other inputs, like capital, and since the returns from it will be high-marginal benefits are expected to be high. The specification is sound given that Prob>chi2 is less than 5\%.

Table 3: Macro Economic Variables

\begin{tabular}{|c|c|c|c|}
\hline lemp & Coef. & $\mathbf{Z}$ & $p>|z|$ \\
\hline lreer & .34 & 1.83 & 0.067 \\
\hline lgdp & 1.61 & 2.16 & 0.031 \\
\hline loip & .06 & 1.75 & 0.081 \\
\hline $11 \mathrm{p}$ & -.91 & -3.07 & 0.002 \\
\hline -cons & -13.26 & -1.25 & 0.210 \\
\hline
\end{tabular}

After controlling for sector specifics in the model with control variables, Table 4 presents the results with oil prices now being insignificant. However, each sector positively contributes to employment, with the finance sector leading. 
Table 4: Checking With Control Variables

\begin{tabular}{lccc}
\hline \multicolumn{1}{c}{ lemp } & Coef. & t value & p value \\
\hline lreer & .34 & 1.61 & 0.109 \\
\hline lgdp & 1.61 & 2.90 & 0.004 \\
\hline loip & .06 & .62 & 0.538 \\
\hline llp & -.91 & -1.98 & 0.049 \\
\hline sector & & & \\
\hline Government General & .27 & 4.10 & 0.000 \\
Government & & & 0.000 \\
\hline Construction & .61 & 9.21 & 0.000 \\
\hline Finance & 1.34 & 20.28 & 0.000 \\
\hline Mining & .34 & 5.07 & 0.006 \\
\hline Manufacturing & .18 & 2.76 & 0.000 \\
\hline Trade & .46 & 6.99 & 0.014 \\
\hline -cons & -34.72 & -2.26 & \\
\hline
\end{tabular}

\section{Diagnostic Test}

Finally, an LM test was done to verify whether running a simple Ordinary Least Squares or random effects model was the best. When Prob>chi2 above 10\%, the tests fail to reject the null and conclude that random effects are not appropriate. In this study, the null hypothesis was rejected and the study concludes that random effects are appropriate. This is evidence of significant differences across sectors; therefore, it was best not to run a simple OLS regression.

\section{CONCLUDING REMARKS AND IMPLICATIONS FOR POLICY}

This paper examined the impact of oil prices on sectorial employment in South Africa. By employing the panel data analysis for seven sub-sectors - two in the public sector (general government and government enterprises) and five in the private sector (mining, manufacturing, construction, trade and finance), the paper supports the view that factor prices (oil) have a significant impact on employment in South Africa. Results suggest that oil price increases affect mainly employment in the private sector, especially finance, construction and trade. In the public sector (general government and business enterprises), however, oil prices were found to be insignificant in explaining employment levels. When considering other control variables, Gross Domestic Product (GDP), Real Effective Exchange Rate (REER) were found to be significant and positively related with employment. Labour Productivity (LP), on the other hand, was significant and negatively related to employment.

In considering the effect of oil prices on employment, analysis is focused on how oil prices affect real wages and then employment. Given the wage rate, an increase in the price of oil leads to an increase in price level, thus a decrease in real (consumption) wage. However, the actual outcome then depends on the following phenomenon: In the presence of real wage resistance, wage increase leads to further price increases. On the other hand, monetary policy matters. If monetary policy is accommodative, the outcome is inflation; however, if nonaccommodative, this would result in higher unemployment in order to limit wage increases. The question of impact of oil prices on employment is therefore an issue of how accommodative is the monetary policy. Also, the ability of resistance wage is pinned on the strength of unions (unionization of the labour market), with a weakly unionized market displaying low wage resistance. South Africa's monetary policy is accommodative; therefore, the outcome of an increase in oil prices is inflation, rather than employment. The increase in inflation in turn reduces the real wage in South Africa, hence the significant positive relationship between oil prices and sectorial employment in South Africa.

The implication is that the government further tightens the monetary policy to deal with inflation expectations and actual inflation in the face of oil price increases. Oil prices seem to affect inflation more than it does with unemployment. With an oil price increase under an accommodative monetary policy, people expect an increase in inflation more than their fear of losing their jobs. The behaviour of the households is well explained by the rational expectations theory which is that households make an economic behavior observation of which, on average, they can quite correctly predict future conditions and take actions accordingly (Sinclair, 2010). In addition, 
Sinclair (2010) contends that households make rational predictions, even if they may not fully understand the cause and effect (causal) relationships underlying the events and their own thinking. South Africa, being a net oil importer, cannot influence international oil prices; therefore, the authors argue that the government puts more emphasis on curbing excessive inflation expectations resulting from oil price increases as these are more damaging to an economy using inflation-targeting framework.

\section{AUTHOR INFORMATION}

Kin Sibanda is a holder of a Master of Commerce in Economics at the University of Fort Hare. He is a PhD (Economics) student in the Department of Economics at the University of Fort Hare in South Africa and his research interests include monetary economics, development finance, environmental economics and macroeconomic theory. $\mathrm{He}$ is in the advanced stages of his PhD in Economics: E-mail: keith08.kin@ gmail.com.

Syden Mishi is a holder of a Master of Commerce in Economics at the University of Fort Hare. He is a Lecturer in the Department of Economics at the University of Fort Hare with research interests in applied economics: development finance (including migrations, remittances and poverty related studies), international finance, and financial markets analysis, monetary economics. Syden has taught monetary economics, macroeconomics, mathematical economics, financial economics, and labour economics. He is in the advanced stages of doctorate studies in the area of banking and finance. Email: smishi@ufh.ac.za.

Asrat Tsegaye is a Professor of Economics at the University of Fort Hare. He holds a doctorate in economics from the University of Kent at Canterbury. He has lectured and researched in several countries in Africa, including Zimbabwe, Botswana, and currently in South Africa. He is a member of the Academic Committee of the Economic Research Southern Africa (ERSA) and is currently lecturing and coordinating several projects in the Department of Economics at the University of Fort Hare. He is also a member of the Faculty's Research and Higher Degrees Committee. Email: atsegaye@ufh.ac.za.

\section{REFERENCES}

Ahmad, F. (2013). The effects of oil prices on unemployment: evidence from Pakistan. Journal of Business and economic Research, 4(1), 43-57.

Beaudreau, B, C. (2005). Engineering and economic growth, Journal of Structural Change and Economic Dynamics, $16(2), 211-220$.

Blanchard, O. J., \& Gali, J. (2007). The macroeconomic effects of oil price shocks: why are 2000's so different from the 1970's? National Bureau of Economic Research Working Paper 13368.

Bletcher, E., Thomas, K., Muradzikwa, S., Smith, L., \& De Villiers, P. (2009). Economics. Second edition. New York: Oxford.

Brown, S., \& Yucel, M. (2002). Energy prices and aggregate economic activity: an interpretative Survey, Quarterly Review of Economics and Finance, 42 (2), 193-208.

Burbridge, J., \& Harrison, A. (1984). Testing for the Effects of Oil-Price Rises Using Vector Autoregressions, International Economic Review, Vol. 25, No.1, pp. 459-484.

Chisadza, C., Dlamini, J., Gupta, R., \& Modise, M. P. (2013). The impact of oil shocks on the South African economy. Forthcoming in Energy Sources, Part B: Economics, Planning, and Policy.

Dogrul, G. H., \& Soytas, U. (2010). Relationship between oil prices, interest rate, and unemployment: evidence from an emerging market, Energy Economics, 32, 1523-1528.

Energy Information Administration. (2013). OPEC Revenues: Country Details. [Online]. Available http://www.eia.doe.gov Accessed 16 September 2013.

Hamilton, J. D. (1983). Oil and the Macroeconomy since World War II, Journal of Political Economy, 91, 228-248.

Herrera, A. M., \& Karaki, M. B. (2012). Effects of oil price shocks on job reallocation. Working paper. University of Kentucky, UK.

Keane, M. P., \& Prasad, E. S. (1996). The employment and wage effects of oil price changes: a sectorial analysis. The Review of Economics and Statistics, 78(3), 389-400.

Kilian, L., \& Vigfusson, R. J. (2011). Are the responses of the U.S. economy asymmetric in energy price increases and decreases? Quantitative Economics, 2(3), 419-453. 
Knight, R. (2001). South Africa: Economic policy and development. [Online] available: K:ISouth Africa Economic Policy and Development.mht [accessed on 06-08-2010].

Leibbrandt, M., Woolard, I., \& McEwen, H. (2010). Employment and Inequality Outcomes in South Africa: What Role for Labour Market and Social Policies? Southern Africa Labour and Development Research Unit, University of Cape Town.

McCaffrey, D. F., Mihaly, K., Lockwood, J. R., \& Sass, T. R. (2012). A review of Stata commands for fixed-effects estimation in normal linear models. Stata Journal 12: 406-432.

New Growth Path. (2010). The New Growth Path: The Framework. [Online]. Availablehttp://www.info.gov.za/view/DownloadFileAction?id=135748 Accessed 16 September 2013.

Ngandu, S, N.C. (2009). The impact of exchange rate movements on employment: The economy wide effect of a rand appreciation. Journal of Development Southern Africa, 26(1).

Nkomo, J. C. (2006). Crude oil price movements and their impact on South Africa. Energy Research Centre, University of Cape Town Journal of Energy in Southern Africa, 17(4).

Rajhi, T., Benabdallah, M., \& Hmissi, W. (2005). Impact of oil shocks on African economies. Available.http://www.afdb.org/fileadmin/uploads/afdb/Documents/Knowledge/09484255-FR-IMPACTOFOIL-SHOCKS-ON-AFRICAN-ECONOMIES.PDF.

Sinclair, P. (2010). Inflation expectations and empirical tests. New York: Routlegde Taylor and Francis Group.

Trading Economics. (2012). South Africa Unemployment Rate. [Online]. Available http://www.tradingeconomics.com/south-africa/unemployment-rate[Accessed on 30 February, 2013].

Wakeford, J. (2006). The impact of oil price shocks on the South African macroeconomy: history and prospects. Paper presented at Accelerated and Shared Growth in South Africa: Determinants, Constraints and Opportunities, The Birchwood Hotel and Conference Centre, Johannesburg, South Africa, 18-20 October. 


\section{NOTES}

